\title{
The impact of serum adropin and ischemia modified albumin levels based on BMI in PCOS
}

Stężenia adropiny i albuminy modyfikowanej niedokrwieniem w surowicy w zależności od występowania zespołu policystycznych jajników i wartości BMI

\section{Zeynep Ozturk Inal', Sami Erdem², Yavuz Gederet', Cevdet Duran³, Zehra Kucukaydin', Huseyin Kurku², Derya Kilic Sakarya ${ }^{1}$}

${ }^{1}$ Konya Education and Research Hospital, Department of Obstetrics and Gynecology, Konya, Turkey

${ }^{2}$ Konya Education and Research Hospital, Department of Biochemistry, Konya, Turkey

${ }^{3}$ Konya Education and Research Hospital, Department of Endocrinology, Konya, Turkey

\begin{abstract}
Introduction: The aim of this study was to evaluate the effects of polycystic ovary syndrome (PCOS) and body mass index (BMI) on serum adropin and ischemia modified albumin (IMA) levels.

Material and methods: This prospective cross-sectional study was performed with a total of 120 women [group1; non-PCOS $=60$ (BMI $<25=30, \mathrm{BMI} \geq 25=30$ ) and group 2; PCOS $=60(\mathrm{BMI}<25=30, \mathrm{BMI} \geq 25=30)$ ]. Blood samples were collected between the third and fifth days of the women's menstrual cycles after a night of fasting.

Results: There were no differences between the groups in relation to age, basal follicle stimulating hormone, estradiol, thyroid stimulating hormone, prolactin, high-density lipoprotein cholesterol, total testosterone, dehydroepiandrosterone sulfate levels, systolic and diastolic blood pressures. A significant difference was found in basal luteinizing hormone, fasting glucose, insulin, homeostatic model assessment of insulin resistance, total cholesterol, low-density lipoprotein cholesterol, triglycerides, free testosterone levels, waist-to-hip ratios and the Ferriman-Gallwey scores between the PCOS and non-PCOS patients in the lean and overweight groups $(\mathrm{P}<0.05)$. The serum adropin levels in the lean PCOS group were lower than in the lean non-PCOS group $(\mathrm{P}<0.05)$ and were lower in the overweight PCOS group than in the overweight non-PCOS group $(\mathrm{P}<0.05)$. There was also a statistically significant difference in serum IMA levels in the PCOS group than in the non-PCOS group in both the lean and overweight groups $(\mathrm{P}<0.05)$.

Conclusions: Although serum adropin levels were significantly decreased in the PCOS group, IMA levels increased. Further studies are needed to determine the effects of adropin and IMA in women with PCOS and to use a new marker to monitorize treatment outcomes. (Endokrynol Pol 2018; 69 (2): 135-141)
\end{abstract}

Key words: adropin, ischemia modified albumin (IMA), insulin resistance, polycystic ovary syndrome (PCOS)

\section{Streszczenie}

Wstęp: Badanie przeprowadzono w celu oceny wpływu zespołu policystycznych jajników (polycystic ovary syndrome, PCOS) i wskaźnika masy ciała (body mass index, BMI) na surowicze stężenia adropiny i albumin modyfikowanej niedokrwieniem (ischemia modified albumin, IMA). Material i metody: To prospektywne badanie przekrojowe obejmowało 120 kobiet [grupa 1: osoby bez PCOS $-\mathrm{n}=60$ (BMI $<25-$ $n=30 ; B M I \geq 25-n=30)$ oraz grupa 2: osoby z PCOS $-n=60(B M I<25-n=30$, BMI $\geq 25-n=30)$ ]. Próbki krwi pobierano między trzecim a piątym dniem cyklu menstruacyjnego badanych kobiet, rano na czczo.

Wyniki: Grupy nie różniły się pod względem wieku, podstawowego stężenia hormonu folikulotropowego, stężeń estradiolu, tyreotropiny, prolaktyny, cholesterol frakcji HDL, testosteronu całkowitego i siarczanu dehydroepiandrosteronu ani skurczowego i rozkurczowego ciśnienia tętniczego. Stwierdzono natomiast istotne różnice między grupą z PCOS i bez PCOS w podgrupach osób szczupłych i otyłych w zakresie podstawowego stężenia hormonu luteinizującego, glikemii na czczo, wskaźnika insulinooporności w modelu homeostazy, stężeń cholesterolu całkowitego, cholesterolu frakcji LDL, triglicerydów i wolnego testosteronu, a także wskaźnika talia-biodra oraz oceny w skali Ferrimana-Gallweya $(\mathrm{P}<0,05)$. Stężenia adropiny w osoczu były niższe w grupie szczupłych kobiet z PCOS niż u szczupłych osób niechorujących na PCOS $(\mathrm{P}<0,05)$ oraz były niższe u otyłych osób z PCOS niż u otyłych osób z grupy bez PCOS $(\mathrm{P}<0,05)$. Stwierdzono również statystycznie istotną różnice w stężeniach IMA w surowicy między kobietami z PCOS i bez PCOS, zarówno w podgrupie osób szczupłych, jak i otyłych $(\mathrm{P}<0,05)$.

Wnioski: Mimo że surowicze stężenia adropiny były istotnie niższe w grupie z PCOS, stężenia IMA były podwyższone w tej grupie badanych. Konieczne są dalsze badania w celu określenia wpływu adropiny i IMA u kobiet z PCOS i stosowanie nowych wskaźników do monitorowania efektów leczenia. (Endokrynol Pol 2018; 69 (2): 135-141)

Słowa kluczowe: adropina, albumina modyfikowana niedokrwieniem (IMA), insulinooporność, zespół policystycznych jajników (PCOS) 


\section{Introduction}

Polycystic ovary syndrome (PCOS), which can cause hormonal, metabolic, and reproductive anomalies and is seen in $5-10 \%$ of women of reproductive age, is a chronic inflammatory endocrinopathy [1]. The etiology of PCOS, a complex heterogeneous disease thought to play a role in genetic and environmental factors, is not fully understood. Basic features of PCOS include ovulatory dysfunction, biochemical and clinical hyperandrogenism, and polycystic ovary appearance on ultrasonography (USG) [1,2]. Defensive steroid biosynthesis and hyperinsulinemia associated with obesityindependent insulin resistance (IR) may increase the hyperandrogenism findings [2]. PCOS is associated with an increased risk of type 2 diabetes mellitus (DM) and cardiovascular disease due to atherosclerosis, metabolic syndrome, hyperlipidemia, hypertension, obesity, and oxidative stress. PCOS is also associated with infertility due to decreased oocyte maturation, fertilization, embryogenesis and miscarriage, preeclampsia, diabetesrelated congenital abnormalities [3-6].

Adropin, which was discovered for the first time in 2008 by Kumar et al. [7], is a product of the energy homeostasis-associated (Enho) gene and a peptidestructured hormone containing 42 aminoacid, and is thought to play a role in the regulation of energy homeostasis and endothelial function [3, 7-10]. Lower adropin levels are associated with IR independent of obesity, dyslipidemia, hepatic steatosis, and increased fat mass. Overexpression or exogenous administration improves glucose homeostasis and increases blood flow and capillary density in rodents; it also has an endothelial protective role by increasing eNOS expression $[7,11]$. Circulating adropin levels were found to be low in DM, gestational DM, metabolic syndrome, non-alcoholic fatty liver disease, PCOS, and coronary artery disease $[5,9,10,12,13]$.

It has been reported that a change of $\mathrm{N}$ terminal structure of albumin occurs in cases of ischemic states in the human body, and a new molecule named ischemiamodified albumin (IMA), which cannot bind metal ions, is created [6, 14]. Higher IMA levels are observed more often in cases of myocardial ischemia, but can also increase in cases of type $2 \mathrm{DM}$, pulmonary embolism, liver cirrhosis, metabolic syndrome, and intrauterine pathologies [14, 15]. To our knowledge, serum IMA levels in patients with PCOS are in conflict with the literature. In addition to a study revealing that serum IMA levels did not change in patients with PCOS [16], other studies have shown that higher serum IMA levels are increasingly common $[6,17,18]$.

In the current study, our aim was to investigate serum levels of adropin and IMA in women with PCOS.

\section{Material and methods}

A prospective sequential cross-sectional study was performed with a total of 120 women between January and December 2016 at the department of obstetric and gynecology, Konya Research and Education Hospital. Sixty PCOS patients and 60 age-and-BMI-matched non-PCOS patients with normal menstrual cycles were consecutively included. Clinical and demographic characteristics of all patients were evaluated by a single investigator. One hundred and twenty blood samples were analyzed. Patients were divided into subgroups according to BMI (BMI $<25$ was considered lean and $\mathrm{BMI} \geq 25$ was considered overweight). This study was approved by the local ethics committee and the institutional review board.

Written and oral informed consent was obtained from all volunteers. The ethical principles for medical research involving human subjects stipulated in the 18th World Medical Association Declaration of Helsinki were applied. The BMI values and hormonal, biochemical, and ultrasonographic parameters were recorded. Sixty women (BMI $<25=30, \mathrm{BMI} \geq 25=30$ ) were diagnosed with PCOS according to the menstrual, laboratory, and ultrasonographic criteria defined by a consensus workshop sponsored by ESHRE/ASRM in Rotterdam in May 2003 [19]. It includes: $i=$ menstrual disorders oligoovulation/anovulation); $\mathrm{ii}=$ clinical and/ or biochemical evidence of hyperandrogenism; and iii $=$ polycystic ovaries on ultrasound examination (at least 10 follicles $2-9 \mathrm{~mm}$ in size or the volume of the ovary greater than $10 \mathrm{~mL})$. Sixty non-PCOS women [(BMI < $25=30, \mathrm{BMI} \geq 25=30$ )] were evaluated as the control group. The Ferriman-Gallwey (FG) method was used to determine hirsutism [20]. Subjects were accepted as hirsute if their FG scores were $\geq 8$. Biochemical hyperandrogenism was defined as an increase in the serum concentrations of free testosterone (normal values: 0.46-2.48 pg/dL) and/or total testosterone (normal values $0.15-0.7 \mathrm{ng} / \mathrm{mL}$ ), according to manufacturer's instructions.

Control subjects were included from healthy women who visited the gynecology clinic for routine gynecological examination. The women in the control group had regular menstrual cycles (28-32 days) and no concomitant health problems or signs of hyperandrogenism.

The exclusion criteria were age $<18$ or $>35$ years, BMI $\geq 35 \mathrm{~kg} / \mathrm{m}^{2}$, evidence of clinical hyperandrogenemia (Cushing's syndrome, hyperprolactinemia, congenital adrenal hyperplasia, diseases of the adrenal gland,thyroid disorders, galactorrhea, breastfeeding, and pregnancy); type 1/type 2 diabetes; hypertension; active or chronic liver or renal failure, a history of coro- 
nary artery disease; acute infection (within 14 days); the presence of any chronic inflammatory orautoimmune disease; known malignancy; hormonal contraception and/or anti-androgen therapy (within 6 months); and tobacco or alcohol use.

\section{Study protocol}

Anthropometric measurements including weight, height, and waist-to-hip ratio were peformed following detailed anamnesis and physical and gynecological examinations. Measurements of height and weight were performed with the subjects in light clothing. The BMI was calculated using the weight by the square of the height (weight $/$ height $^{2}-\mathrm{kg} / \mathrm{m}^{2}$ ). Waist circumference $(\mathrm{cm})$ was measured midway between the lower rib margin and the iliac crest at the level of the umbilicus during expiration. Hip circumference was calculated at the widest circumference at the level of the buttocks, and the waist-to-hip ratio (WHR) was calculated to assess body-fat distribution. Blood pressure was measured in the sitting position after a rest period of at least 5 minutes. IR was calculated using homeostatic model assessment of insulin resistance (HOMA-IR) and was calculated according to the following formula: fasting insulin $(\mu \mathrm{IU} / \mathrm{mL}) \times$ fasting glucose $(\mathrm{mmol} / \mathrm{L}) / 22.5)[21]$.

\section{Biochemical evaluation}

Venous blood samples were collected from the antecubital veins of all subjects from 8:00 a.m. and 10:00 a.m., between the third and fifth days of the menstrual cycle after a night of fasting. The plasma samples were stored at $-80^{\circ} \mathrm{C}$ for adropin and IMA analysis. Thyroid stimulating hormone (TSH), prolactin, follicle stimulating hormone (FSH), luteinizing hormone (LH), estradiol $\left(\mathrm{E}_{2}\right)$, fasting blood glucose (FBG), serum insulin, hs-CRP, total cholesterol, triglycerides (TG), high-density lipoprotein cholesterol (HDL-C), low-density lipoprotein cholesterol (LDL-C), free testosterone, total testosterone, dehydroepiandrosterone sulfate (DHEA-S), adropin, and IMA levels were measured on the day of sampling.

Serum FBG, hs-CRP, total cholesterol, HDL-C, LDL$\mathrm{C}$, and TG levels were measured by commercially available kits based on routine methods on the Olympus AU 5800 auto-analyzer (Beckman Coulter Inc., Fullerton, CA, USA).

Serum TSH, PRL, FSH, LH, testosterone, and $\mathrm{E}_{2}$ levels were measured by Advia Centaw XP systems (Siemens Healthcare Diagnostics, Germany). Serum free testosterone was measured by Radio Immune Assay method (LB 2111 Multi Crystal Gamma CounterBerthold, Germany).

Serum insulin and DHEA-S levels (NR:6-27mIU/mL) were measured by Immulite 2000 with the chemilumi- nescence immunometric method (Siemens Healthcare Diagnostics). The analytic sensitivity of the assay was $2 \mathrm{mlU} / \mathrm{mL}$. Intra-assay variations as coeefficients of variation $(\mathrm{CVs})$ for various insulin values were $5.5 \%$ (7.67 mlU/mL), 4.0\% (12.5 mlU/mL), 3.3\% (17.2 mlU/ $\mathrm{mL}), 3.9 \%(26.4 \mathrm{mlU} / \mathrm{mL}), 3.8 \%(100 \mathrm{mlU} / \mathrm{mL})$, and $3.7 \%$ (291 $\mathrm{mlU} / \mathrm{mL})$. Interassay variations for the insulin concentrations mentioned above were $7.3 \%, 4.9 \%, 4.1 \%$, $5 \%, 4.2 \%$, and $5.3 \%$, respectively.

Serum adropin concentrations were measured by an enzyme-linked immunosorbent assay kit (Catalog No. 201-12-3107 Sunred Biological Technology Co., Shanghai, PRC) as recommended by the manufacturer's protocol. CVs for intra-assay were $<9 \%$; CVs for inter assay were $<11 \%$; sensitivity was $4,735 \mathrm{pg} / \mathrm{mL}$; and assay range was $5-1000 \mathrm{pg} / \mathrm{mL}$.

Serum IMA concentrations were measured by an enzyme-linked immunosorbent assay kit (Catalog No. 201-12-1173 Sunred Biological Technology Co., Shanghai, PRC) as recommended by the manufacturer's protocol. Sensitivity was $2,226 \mathrm{ng} / \mathrm{mL}$; assay range was 3-600 ng/mL.

\section{Statistical analysis}

We used the SPSS 15 (Statistical Package for Social Sciences, SPSS Inc) software for statistical analyses. The distributions of all of the continuous variables for normal or abnormal distributions were tested using Shapiro-Wilk test. The homogenity of variances was evaluated using the Levene Test. Metric discrete and continuous variables are expressed as the mean $\pm \mathrm{SD}$, where applicable. Nominal data were expressed as the number of cases and percentages. Though the normal distributed variables between groups were compared using Student's $t$ test, the Mann-Whitney $U$ test was applied to the abnormal distributed variables. Nominal data were analyzed using Pearson's Chi square or Fisher's exact test, when appropriate. A $p$ value $<0.05$ was considered statistically significant. However, for all multiple comparisons, the Bonferroni adjustment was applied to control for Type I error.

\section{Results}

Table I describes demographic and clinical characteristics in patients based on PCO and BMI. No statistically significant differences were found between the groups in relation to age, basal FSH and estradiol, HDL-C, total testosterone, and DHEA-S, TSH, prolactin levels, systolic and diastolic blood pressures. There was a significant difference in basal LH, fasting glucose, insulin, HOMA-IR, total cholesterol, LDL-C, triglyceride, and free testosterone levels, waist-to-hip ratio and FG score between the PCOS and non-PCOS patients in the lean 
Table I. Demographic and clinical characteristics in patients based on PCO and BMI

Tabela I. Demograficzna i kliniczna charakterystyka chorych w zależności od występowania zespołu policystycznych jajników (polycystic ovary syndrome, PCOs) i wartości wskaźnika masy ciała (body mass index, BMI)

\begin{tabular}{|c|c|c|c|c|c|c|c|}
\hline Variables & $\begin{array}{l}\text { Non-PCOS } \\
(\mathrm{n}=60)\end{array}$ & $\begin{array}{l}\text { PCOS } \\
(n=60)\end{array}$ & p-value ${ }^{a}$ & Variables & $\begin{array}{l}\text { Non-PCOS } \\
(\mathrm{n}=60)\end{array}$ & $\begin{array}{l}\text { PCOS } \\
(n=60)\end{array}$ & p-value ${ }^{a}$ \\
\hline \multicolumn{4}{|l|}{ Age [years] } & \multicolumn{4}{|l|}{ Insulin } \\
\hline${ }^{*} \mathrm{BMl}<25 \mathrm{~kg} / \mathrm{m}^{2}$ & $25.30 \pm 5.59$ & $25.91 \pm 4.60$ & 0.644 & ${ }^{*} \mathrm{BMl}<25 \mathrm{~kg} / \mathrm{m}^{2}$ & $5.80 \pm 5.04$ & $12.68 \pm 8.07$ & $<0.001$ \\
\hline${ }^{*} \mathrm{BMI} \geq 25 \mathrm{~kg} / \mathrm{m}^{2}$ & $26.97 \pm 5.24$ & $27.22 \pm 4.52$ & 0.845 & ${ }^{*} \mathrm{BMI} \geq 25 \mathrm{~kg} / \mathrm{m}^{2}$ & $6.87 \pm 3.94$ & $15.89 \pm 13.37$ & $<0.001$ \\
\hline$p$-value ${ }^{b}$ & 0.238 & 0.274 & & $p$-value ${ }^{b}$ & 0.361 & 0.271 & \\
\hline \multicolumn{4}{|l|}{$\mathrm{TSH}[\mu \mathrm{lU} / \mathrm{mL}]$} & \multicolumn{4}{|l|}{ HOMA-IR [mg/dL] } \\
\hline${ }^{*} \mathrm{BMI}<25 \mathrm{~kg} / \mathrm{m}^{2}$ & $2.19 \pm 1.20$ & $1.72 \pm 1.10$ & 0.123 & ${ }^{*} \mathrm{BMl}<25 \mathrm{~kg} / \mathrm{m}^{2}$ & $1.11 \pm 1.08$ & $2.70 \pm 1.89$ & $<0.001$ \\
\hline $\begin{array}{l}{ }^{* *} \mathrm{BMI} \geq 25 \mathrm{~kg} / \mathrm{m}^{2} \\
p \text {-value }\end{array}$ & $\begin{array}{l}1.83 \pm 1.08 \\
0.227\end{array}$ & $\begin{array}{l}1.32 \pm 0.95 \\
0.133\end{array}$ & 0.057 & ${ }^{* *} \mathrm{BMI} \geq 25 \mathrm{~kg} / \mathrm{m}^{2}$ & $1.39 \pm 0.72$ & $3.43 \pm 3.19$ & 0.002 \\
\hline \multicolumn{4}{|l|}{ Prolactin [ng/mL] } & $p$-value ${ }^{b}$ & 0.361 & 0.271 & \\
\hline${ }^{*} \mathrm{BMl}<25 \mathrm{~kg} / \mathrm{m}^{2}$ & $11.32 \pm 8.60$ & $14.32 \pm 7.47$ & 0.155 & \multicolumn{4}{|l|}{ Insulin resistance [\%] } \\
\hline${ }^{* *} \mathrm{BMI} \geq 25 \mathrm{~kg} / \mathrm{m}^{2}$ & $12.56 \pm 6.81$ & $15.50 \pm 8.06$ & 0.132 & ${ }^{*} \mathrm{BMI}<25 \mathrm{~kg} / \mathrm{m}^{2}$ & $3(10 \%)$ & $12(40 \%)$ & 0.015 \\
\hline$p$-value ${ }^{b}$ & 0.539 & 0.559 & & ${ }^{* *} \mathrm{BMl} \geq 25 \mathrm{~kg} / \mathrm{m}^{2}$ & $9(30 \%)$ & $21(70 \%)$ & 0.004 \\
\hline \multicolumn{4}{|l|}{ Basal FSH [IU/L] } & $p$-value & 0.104 & 0.037 & \\
\hline${ }^{*} \mathrm{BMI}<25 \mathrm{~kg} / \mathrm{m}^{2}$ & $6.78 \pm 1.65$ & \multirow{3}{*}{$\begin{array}{l}1 . \angle 4 \pm 0.9 \angle \\
7.42 \pm 1.19 \\
0.514\end{array}$} & \multirow{3}{*}{$\begin{array}{l}0.197 \\
0.096\end{array}$} & \multicolumn{4}{|l|}{ LDL-C [mg/dL] } \\
\hline \multirow{2}{*}{$\begin{array}{l}{ }^{*} \mathrm{BMI} \geq 25 \mathrm{~kg} / \mathrm{m}^{2} \\
p \text {-value }\end{array}$} & \multirow{2}{*}{$\begin{array}{l}6.85 \pm 1.40 \\
0.878\end{array}$} & & & ${ }^{*} \mathrm{BMl}<25 \mathrm{~kg} / \mathrm{m}^{2}$ & $109.03 \pm 27.37$ & $125.50 \pm 27.06$ & 0.023 \\
\hline & & & & ${ }^{* *} \mathrm{BMI}>25 \mathrm{~kg} / \mathrm{m}^{2}$ & $114.70 \pm 25.89$ & $135.50 \pm 35.10$ & 0.011 \\
\hline $\begin{array}{l}{ }^{*} \mathrm{BMl}<25 \mathrm{~kg} / \mathrm{m}^{2} \\
\end{array}$ & $6.08 \pm 1.86$ & Basal LH [IU/L] & $<0.001$ & $p$-value ${ }^{b}$ & 0.414 & 0.221 & \\
\hline${ }^{*} \mathrm{BMI} \geq 25 \mathrm{~kg} / \mathrm{m}^{2}$ & $6.28 \pm 1.58$ & $11.47 \pm 6.57$ & $<0.001$ & \multicolumn{4}{|l|}{$\mathrm{HDL}-\mathrm{C}[\mathrm{mg} / \mathrm{dL}]$} \\
\hline$p$-value ${ }^{b}$ & 0.672 & 0.592 & & ${ }^{*} \mathrm{BMl}<25 \mathrm{~kg} / \mathrm{m}^{2}$ & $51.57 \pm 10.30$ & $49.54 \pm 10.22$ & 0.455 \\
\hline \multicolumn{4}{|l|}{ Basal $E_{2}[p g / m L]$} & ${ }^{* *} \mathrm{BMl}>25 \mathrm{~kg} / \mathrm{m}^{2}$ & $47.77 \pm 9.82$ & $45.27 \pm 9.28$ & 0.434 \\
\hline${ }^{*} \mathrm{BMl}<25 \mathrm{~kg} / \mathrm{m}^{2}$ & $56.04 \pm 16.62$ & $51.02 \pm 11.70$ & 0.181 & $p$-value ${ }^{b}$ & 0.149 & 0.246 & \\
\hline${ }^{* *} \mathrm{BMI} \geq 25 \mathrm{~kg} / \mathrm{m}^{2}$ & $52.38 \pm 6.43$ & $49.37 \pm 14.10$ & 0.295 & \multicolumn{4}{|l|}{ Trigycerides [mg/dL] } \\
\hline$p$-value ${ }^{b}$ & 0.268 & 0.626 & & ${ }^{*} \mathrm{BMI}<25 \mathrm{~kg} / \mathrm{m}^{2}$ & $85.90 \pm 20.93$ & $126.27 \pm 26.03$ & $<0.001$ \\
\hline \multicolumn{4}{|l|}{ Waist to hip ratio } & \multirow{2}{*}{$\begin{array}{l}{ }^{*} \mathrm{BMI}>25 \mathrm{~kg} / \mathrm{m}^{2} \\
p \text {-value }\end{array}$} & \multirow{2}{*}{$\begin{array}{l}93.01 \pm 26.89 \\
0.259\end{array}$} & \multirow{2}{*}{$\begin{array}{l}136.17 \pm 24.77 \\
0.137\end{array}$} & \multirow[t]{2}{*}{$<0.001$} \\
\hline${ }^{*} \mathrm{BMI}<25 \mathrm{~kg} / \mathrm{m}^{2}$ & $0.74 \pm 0.11$ & $0.82 \pm 0.09$ & 0.005 & & & & \\
\hline $\begin{array}{l}{ }^{*} \mathrm{BMI} \geq 25 \mathrm{~kg} / \mathrm{m}^{2} \\
p \text {-value }\end{array}$ & $\begin{array}{l}0.79 \pm 0.10 \\
0.125\end{array}$ & $\begin{array}{l}0.92 \pm 0.12 \\
0.001\end{array}$ & $<0.001$ & \multicolumn{4}{|l|}{ hs-CRP [mg/dL] } \\
\hline \multicolumn{4}{|l|}{ SBP [mmHg] } & ${ }^{*} \mathrm{BMI}<25 \mathrm{~kg} / \mathrm{m}^{2}$ & $1.86 \pm 1.81$ & $3.22 \pm 2.78$ & 0.021 \\
\hline${ }^{*} \mathrm{BMI}<25 \mathrm{~kg} / \mathrm{m}^{2}$ & $105.00 \pm 10.74$ & $109.00 \pm 9.94$ & 0.140 & ${ }^{* *} \mathrm{BMI}>25 \mathrm{~kg} / \mathrm{m}^{2}$ & $2.11 \pm 1.55$ & $3.89 \pm 2.90$ & 0.016 \\
\hline${ }^{* *} \mathrm{BMI} \geq 25 \mathrm{~kg} / \mathrm{m}^{2}$ & $102.00 \pm 10.30$ & $106.67 \pm 9.22$ & 0.070 & $p$-value ${ }^{b}$ & 0.703 & 0.364 & \\
\hline$p$-value ${ }^{b}$ & 0.274 & 0.351 & & \multicolumn{4}{|l|}{ Total testosterone [ng/mL] } \\
\hline $\mathrm{DBP}[\mathrm{mmHg}]$ & & & & ${ }^{*} \mathrm{BMl}<25 \mathrm{~kg} / \mathrm{m}^{2}$ & $0.37 \pm 0.13$ & $0.41 \pm 0.15$ & 0.309 \\
\hline${ }^{*} \mathrm{BMI}<25 \mathrm{~kg} / \mathrm{m}^{2}$ & $66.00 \pm 7.70$ & $68.68 \pm 5.07$ & 0.119 & ${ }^{* *} \mathrm{BMI}>25 \mathrm{~kg} / \mathrm{m}^{2}$ & $0.38 \pm 0.12$ & $0.43 \pm 0.11$ & 0.102 \\
\hline${ }^{*} \mathrm{BMI} \geq 25 \mathrm{~kg} / \mathrm{m}^{2}$ & $68.33 \pm 8.33$ & $71.17 \pm 7.84$ & 0.181 & $p$-value ${ }^{b}$ & 0.813 & 0.551 & \\
\hline$p$-value ${ }^{b}$ & 0.265 & 0.149 & & Free testosterone $[\mathrm{pg} / \mathrm{d}$ & & & \\
\hline Ferriman-Gallwey sc & & & & ${ }^{*} \mathrm{BMI}<25 \mathrm{~kg} / \mathrm{m}^{2}$ & $1.15 \pm 0.36$ & $2.33 \pm 0.56$ & $<0.001$ \\
\hline $\begin{array}{l}{ }^{*} \mathrm{BMI}<25 \mathrm{~kg} / \mathrm{m}^{2} \\
{ }^{*} \mathrm{BMl}>25 \mathrm{~kg} / \mathrm{m}^{2}\end{array}$ & $\begin{array}{l}5.83 \pm 1.05 \\
6.361 .58\end{array}$ & $\begin{array}{l}15.90 \pm 6.55 \\
16.63 \pm 6.94\end{array}$ & $\begin{array}{l}<0.001 \\
<0.001\end{array}$ & $*{ }^{*} \mathrm{BMI}>25 \mathrm{~kg} / \mathrm{m}^{2}$ & $1.35 \pm 0.57$ & $2.55 \pm 0.62$ & $<0.001$ \\
\hline $\begin{array}{l}p \text {-value } \\
{ }^{b}\end{array}$ & $\begin{array}{l}6.361 .58 \\
0.131\end{array}$ & $\begin{array}{l}16.63 \pm 0.94 \\
0.676\end{array}$ & $<0.001$ & $p$-value ${ }^{b}$ & 0.117 & 0.173 & \\
\hline Fasting glucose & & & & DHEA-SO $_{4}[\mu \mathrm{g} / \mathrm{dL}]$ & & & \\
\hline${ }^{*} \mathrm{BMl}<25 \mathrm{~kg} / \mathrm{m}^{2}$ & $75.10 \pm 12.81$ & $82.971 \pm 1.63$ & 0.016 & ${ }^{*} \mathrm{BMI}<25 \mathrm{~kg} / \mathrm{m}^{2}$ & $191.08 \pm 97.98$ & $228.88 \pm 99.74$ & 0.148 \\
\hline${ }^{*} \mathrm{BMI} \geq 25 \mathrm{~kg} / \mathrm{m}^{2}$ & $79.23 \pm 6.01$ & $84.17 \pm 9.71$ & 0.021 & ${ }^{* *} \mathrm{BMI}>25 \mathrm{~kg} / \mathrm{m}^{2}$ & $206.98 \pm 69.88$ & $245.63 \pm 102.48$ & 0.094 \\
\hline$p$-value ${ }^{b}$ & 0.115 & 0.611 & & $p$-value ${ }^{b}$ & 0.472 & 0.527 & \\
\hline
\end{tabular}

$\mathrm{BMI}$ — body mass index; TSH — thyroid stimulating hormone; FSH — follicle-stimulating hormone; LH — luteinizing hormone; $\mathrm{E}_{2}$ — estradiol; HOMA-IR — homeostasis model assessment of insulin resistance; LDL-C — low density lipoprotein cholesterol; HDL-C — high density lipoprotein cholesterol; hs-CRP — high sensitivity C-reactive protein; DHEA-S — dehydroepiandrosterone sulfate; ${ }^{*} \mathrm{BMl}<25 \mathrm{~kg} / \mathrm{m}^{2}$ and Non-PCOS n $=30 ; \mathrm{BMI}<25 \mathrm{~kg} / \mathrm{m}^{2}$ and PCOS $\mathrm{n}=30$

${ }^{*} \mathrm{BMI} \geq 25 \mathrm{~kg} / \mathrm{m}^{2}$ and Non-PCOS $\mathrm{n}=30, \mathrm{BMI} \geq 25 \mathrm{~kg} / \mathrm{m}^{2}$ and PCOS $\mathrm{n}=30$; : Comparisons of PCOS and non-PCOS groups. $\mathrm{P}<0.025$ set as statistically significant (Bonferroni adjustment was applied for controlling Type I error). b: Comparisons of BMI groups $p<0.025$ set as statistically significant 
and overweight groups $(\mathrm{P}<0.05)$. Serum adropin and IMA levels, based on BMI and PCOS, are presented in Table II. We detected lower serum adropin levels in the lean PCOS group than in the lean non-PCOS group $(\mathrm{P}<0.05)$ and in the overweight $\mathrm{PCOS}$ group than in the overweight non-PCOS group $(\mathrm{P}<0.05)$. We also noted that there was a statistically significant difference in serum IMA levels in the PCOS group than in the non-PCOS group, in both the lean and overweight groups $(\mathrm{P}<0.05)$.

\section{Discussion}

In the present study, we sought to compare the impact of PCOS and BMI on serum adropin and IMA levels in patients with PCOS. In the PCOS group, although serum adropin levels were lower in lean and overweight patients with PCOS, serum IMA levels were higher than those in non-PCOS women.

The etiopathogenesis of PCOS is not fully known; some genetic and environmental conditions are responsible. It is estimated that IR plays the most important role in PCOS. In $70 \%$ of cases, PCOS can develop independently of obesity; this leads to an increase in androgen production, leading to menstrual disorders, polycystic ovary appearance, and hirsutism [2, 4, 13]. It is also suggested that IR causes glucose intolerance, type $2 \mathrm{DM}$, hypertension, dyslipidemia, and cardiovascular diseases [3-6, 22]. In addition, it is believed that visceral obesity, which is believed to be caused by IR, increases the incidence of DM and cardiovascular disease in patients with PCOS [5, 17]. Because of such conditions, PCOS is now regarded as a complex endocrinological disorder, not as a gynecological disease. While the IR should ideally be assessed using the clamp technique, the HOMA-IR method, which is less invasive, is preferred by clinicians. If the HOMA-IR value is above $2.5 \mathrm{mg} / \mathrm{dL}$, IR is considered [21]. IR was found to be $64 \%$ in a study [23] involving 271 PCOS patients, $30 \%$ in lean PCOS cases, and $95 \%$ in obese PCOS cases in another study [13]. In our study, IR was found in $40 \%$ of the lean PCOS cases and $70 \%$ of the obese PCOS cases, compatible with the literature. It has been reported that oxidative stress, chronic inflammation, and ischemia may cause endothelial dysfunction and increase cardiovascular and metabolic complications in patients with PCOS [7, 11, 17].

In one study, WHR was shown to be increased in obese PCOS patients compared to lean PCOS patients and the control group [24]. In another study, no significant differences were found [17]. In our study, we observed that WHR increases in obese PCOS cases compared to lean PCOS cases and the control group, which is similar to the results in the first study.

There are many studies in the literature researching the relationship between PCOS and inflammatory
Table II. Adropin and IMA levels based on BMI and PCOS

Tabela II. Stężenia adropiny $i$ albuminy modyfikowanej niedokwieniem (ischemia modified albumin, IMA) $w$ zależności od występowania zespołu policystycznych jajników (polycystic ovary syndrome, PCOS) $i$ wartości wskaźnika masy ciała (body mass index, BMI)

\begin{tabular}{llll}
\hline Variables & Non-PCOS & PCOS & p-value \\
\hline $\begin{array}{l}\text { Adropin levels } \\
\text { [ng } / \mathrm{mL}]\end{array}$ & & & \\
${ }^{*} \mathrm{BMl}<25 \mathrm{~kg} / \mathrm{m}^{2}$ & $479.47 \pm 358.18$ & $282.20 \pm 85.22$ & $\mathbf{0 . 0 0 6}$ \\
${ }^{* *} \mathrm{BMI} \geq 25 \mathrm{~kg} / \mathrm{m}^{2}$ & $390.70 \pm 259.25$ & $254.67 \pm 71.18$ & $\mathbf{0 . 0 0 9}$ \\
$p$-value & 0.276 & 0.180 & \\
\hline IMA levels $[\mathrm{ng} / \mathrm{mL}]$ & & & \\
${ }^{*} \mathrm{BMI}<25 \mathrm{~kg} / \mathrm{m}^{2}$ & $182.03 \pm 105.76$ & $294.47 \pm 221.21$ & $\mathbf{0 . 0 1 6}$ \\
${ }^{*} \mathrm{BMI} \geq 25 \mathrm{~kg} / \mathrm{m}^{2}$ & $224.93 \pm 101.91$ & $352.60 \pm 228.31$ & $\mathbf{0 . 0 0 8}$ \\
$p$-value & 0.115 & 0.321 & \\
\hline
\end{tabular}

$\mathrm{BMI}$ — body mass index; IMA — ischemia-modified albumin

${ }^{*} \mathrm{BMI}<25 \mathrm{~kg} / \mathrm{m}^{2}$ and Non-PCOS $\mathrm{n}=30 ; \mathrm{BMI}<25 \mathrm{~kg} / \mathrm{m}^{2}$ and PCOS $\mathrm{n}=30$

** BMl $\geq 25 \mathrm{~kg} / \mathrm{m}^{2}$ and Non-PCOS $\mathrm{n}=30, \mathrm{BMI} \geq 25 \mathrm{~kg} / \mathrm{m}^{2}$ and PCOS $\mathrm{n}=30$

a: Comparisons of PCOS and non-PCOS groups. $P<0.025$ set as statistically significant (Bonferroni adjustment was applied for controlling Type I error). b: Comparisons of BMI groups $p<0.025$ set as statistically significant

markers, including hs-CRP. In addition to studies showing that hs-CRP increases in patients with PCOS [25, 26], studies show that this has not changed $[17,27,28]$. We also found that hs-CRP levels were higher in women with PCOS than in the control group. Higher hs-CRP levels in PCOS patients show that PCOS is a chronic inflammatory disease.

It has been shown that adropin, which is expressed in the central nervous system, liver, heart, and skeletal muscles, is thought to play a role in energy homeostasis; it has also been shown to reduce diets or genetically induced obesity in mice. Additionally, systemic administration or transgenic overexpression reduces IR and hepatosteatosis, and regulates glucose homeostasis $[3,7]$. Adropin deficiency has led to increased fat mass and improved IR in mice [29]. In addition, adropin plays a role in glucose oxidation, activating pyruvate dehydrogenase and lipid oxidation inhibiting carnitine palmitoyl transferase [11]. Another study showed that intraperitoneal adropin administration in type 2 diabetic rats reduced fasting glucose levels, HOMA-IR, triglycerides, and $\mathrm{HbA1c}$, and increased HDL levels [30]. From the aforementioned results, it can be concluded that adropin has a protective role against hepatosteatosis, hyperinsulinemia, and dyslipidemia. In addition, adropin has a protective effect on andothelial functions by increasing nitric-oxide release and activating eNOS [3]. Therefore, we think that adropin can be used as a potential biomarker to anticipate IR. 
It has been shown that circulating adropin levels decreases in GDM, type 2 DM, metabolic syndrome, coronary artery disease, nonalcoholic fatty liver disease, and PCOS. Either adropin levels decreaseas a result of these disorders or lower adropin levels cause these diseases; this situation has not been fully clarified [5, $9,10]$. We also found in our study that, similar to the literature results $[5,9,13]$, the circulating adropin levels in PCOS patients were statistically significantly lower than in the control group.

IMA, a marker of oxidative stress, is considered an indicator of ischemia and chronic hypoxia situation [6]. Chronic hypoxia and oxidative stress may play significant roles in PCOS due to IR [6,17,18]. IMA is a marker often studied in cardiac disorders and has been suggested to be a useful marker in cases of acute coronary syndrome and ischemic stroke [6, 15]. Several studies in the literature research serum IMA levels in patients with PCOS. Although some of them reported higher IMA levels [6, 10], others found no significant difference between PCOS patients and controls [16, 17]. In the present study, we found higher serum IMA levels in PCOS patients than in the control group. These higher IMA concentrations may be in accordance with higher triglyceride and low-density lipoprotein cholesterol levels.

The strengths of our study are that none of the cases in the PCOS and control groups included in the study had received any medical treatment that could affect the outcome of the study, and both groups were completely homegenous.

A potential weakness of our study is that we could not evaluate the visceral fat mass because the necessary method was costly, and the measurement technique was based on ionizing radiation. Another weakness of the current study was that HOMA-IR was used for IR instead of the gold standard method, the clamp technique.

In conclusion, we found that although circulating adropin levels decreased in women with PCOS, serum IMA levels were elevated at the end of our study. Future studies are warranted to clarify the effects of adropin and IMA in metabolic disorders such as PCOS. We believe that the results of our study will shed light on future work.

\section{Compliance with ethical standards Conflict of interest}

The authors report no declarations of interest.

\section{Ethical approval}

This study was approved by the local ethics committee and the institutional review board.

\section{Informed consent}

Written informed consent was obtained from all volunteers.

\section{References}

1. Azziz R, Woods KS, Reyna R, et al. The prevalence and features of the polycystic ovary syndrome in an unselected population. J Clin Endocrinol Metab. 2004; 89(6): 2745-2749, doi: 10.1210/jc.2003-032046, indexed in Pubmed: 15181052.

2. Ehrmann DA. Polycystic ovary syndrome. N Engl J Med. 2005; 352(12): 1223-1236, doi: 10.1056/NEJMra041536, indexed in Pubmed: 15788499.

3. Lovren F, Pan Yi, Quan A, et al. Adropin is a novel regulator of endothelial function. Circulation. 2010; 122(11 Suppl): S185-S192, doi: 10.1161/ CIRCULATIONAHA.109.931782, indexed in Pubmed: 20837912.

4. Inal HA, Yilmaz N, Gorkem U, et al. The impact of follicular fluid adiponectin and ghrelin levels based on BMI on IVF outcomes in PCOS. J Endocrinol Invest. 2016; 39(4): 431-437, doi: 10.1007/s40618-015-0392-6, indexed in Pubmed: 26410834.

5. Kume T, Calan M, Yilmaz O, et al. A possible connection between tumor necrosis factor alpha and adropin levels in polycystic ovary syndrome. J Endocrinol Invest. 2016; 39(7): 747-754, doi: 10.1007/s40618-016-0453-5, indexed in Pubmed: 26969461.

6. Beyazit F, Yilmaz N, Balci O, et al. Evaluation of Oxidative Stress in Women with Polycystic Ovarian Syndrome as Represented by Serum Ischemia Modified Albumin and Its Correlation with Testosterone and Insulin Resistance. Intern Med. 2016; 55(17): 2359-2364, doi: 10.2169/ internalmedicine.55.6265, indexed in Pubmed: 27580534.

7. Kumar KG, Trevaskis JL, Lam DD, et al. Identification of adropin as a secreted factor linking dietary macronutrient intake with energy homeostasis and lipid metabolism. Cell Metab. 2008; 8(6): 468-481, doi: 10.1016/j.cmet.2008.10.011, indexed in Pubmed: 19041763.

8. Aydin S, Kuloglu T, Aydin S, et al. Expression of adropin in rat brain, cerebellum, kidneys, heart, liver, and pancreas in streptozotocin-induced diabetes. Mol Cell Biochem. 2013; 380(1-2): 73-81, doi: 10.1007/s11010013-1660-4, indexed in Pubmed: 23620340.

9. Yildirim B, Celik O, Aydin S. Adropin: a key component and potential gatekeeper of metabolic disturbances in policystic ovarian syndrome. Clin Exp Obstet Gynecol. 2014; 41(3): 310-312, indexed in Pubmed: 24992783.

10. Sayın O, Tokgöz Y, Arslan N. Investigation of adropin and leptin levels in pediatric obesity-related nonalcoholic fatty liver disease. J Pediatr Endocrinol Metab. 2014; 27(5-6): 479-484, doi: 10.1515/jpem-2013-0296, indexed in Pubmed: 24468600.

11. Gao Su, McMillan RP, Jacas J, et al. Regulation of substrate oxidation preferences in muscle by the peptide hormone adropin. Diabetes. 2014; 63(10): 3242-3252, doi: 10.2337/db14-0388, indexed in Pubmed: 24848071.

12. Celik E, Yilmaz E, Celik O, et al. Maternal and fetal adropin levels in gestational diabetes mellitus. J Perinat Med. 2013; 41(4): 375-380, doi: 10.1515/jpm-2012-0227, indexed in Pubmed: 23314506.

13. Sen H, Erbag G, Binnetoglu E, et al. Adropin Levels in Polycystic Ovary Syndrome Patients. J Clin Anal Med. 2017; 8: 23-6.

14. Sbarouni E, Georgiadou P, Voudris V. Ischemia modified albumin changes - review and clinical implications. Clin Chem Lab Med. 2011; 49(2): 177-184, doi: 10.1515/CCLM.2011.037, indexed in Pubmed: 21083441.

15. Duarte MM, Rocha JBT, Moresco RN, et al. Association between ischemiamodified albumin, lipids and inflammation biomarkers in patients with hypercholesterolemia. Clin Biochem. 2009; 42(7-8): 666-671, doi: 10.1016/j.clinbiochem.2009.01.010, indexed in Pubmed: 19318029.

16. Cakir E, Ozbek M, Ozkaya E, et al. Oxidative stress markers are not valuable markers in lean and early age of polycystic ovary syndrome patients. J Endocrinol Invest. 2011; 34(7): e178-e182, doi: 10.3275/7352, indexed in Pubmed: 21088474.

17. Ozturk M, Keskin U, Ozturk O, et al. Are serum gamma-glutamyl transferase, high-sensitivity C-reactive protein, and ischaemia-modified albumin useful in diagnosing PCOS? J Obstet Gynaecol. 2016; 36(7): 929-934, doi: 10.1080/01443615.2016.1174827, indexed in Pubmed: 27183992

18. Caglar GS, Oztas E, Karadag D, et al. Ischemia-modified albumin and cardiovascular risk markers in polycystic ovary syndrome with or without insulin resistance. Fertil Steril. 2011; 95(1): 310-313, doi: 10.1016/j. fertnstert.2010.06.092, indexed in Pubmed: 20701906.

19. Rotterdam ESHRE/ASRM-Sponsored PCOS Consensus Workshop Group, Rotterdam ESHRE/ASRM-Sponsored PCOS consensus workshop group. Revised 2003 consensus on diagnostic criteria and long-term health risks related to polycystic ovary syndrome. Fertil Steril. 2004; 81(1): 19-25, indexed in Pubmed: 14711538.

20. FERRIMAN D, GALLWEY JD. Clinical assessment of body hair growth in women. J Clin Endocrinol Metab. 1961; 21: 1440-1447, doi: 10.1210/ jcem-21-11-1440, indexed in Pubmed: 13892577. 
21. Matthews DR, Hosker JP, Rudenski AS, et al. Homeostasis model assessment: insulin resistance and beta-cell function from fasting plasma glucose and insulin concentrations in man. Diabetologia. 1985; 28(7): 412-419, doi: 10.1007/bf00280883, indexed in Pubmed: 3899825.

22. Mukherjee S, Maitra A. Molecular \& genetic factors contributing to insulin resistance in polycystic ovary syndrome. Indian J Med Res. 2010; 131: 743-760, indexed in Pubmed: 20571162.

23. DeUgarte CM, Bartolucci AA, Azziz R. Prevalence of insulin resistance in the polycystic ovary syndrome using the homeostasis model assessment. Fertil Steril. 2005; 83(5): 1454-1460, doi: 10.1016/j.fertnstert.2004.11.070, indexed in Pubmed: 15866584.

24. Thathapudi S, Kodati V, Erukkambattu J, et al. Anthropometric and Biochemical Characteristics of Polycystic Ovarian Syndrome in South Indian Women Using AES-2006 Criteria. Int J Endocrinol Metab. 2014 12(1): e12470, doi: 10.5812/ijem.12470, indexed in Pubmed: 24696694.

25. Kahyaoglu I, Yllmaz N, Timur H, et al. Granulocyte colony-stimulating factor: A relation between serum and follicular fluid levels and in-vitro fertilization outcome in patients with polycystic ovary syndrome. Cytokine. 2015; 74(1): 113-116, doi: 10.1016/j.cyto.2014.09.002, indexed in Pubmed: 25258001
26. Hu W, Qiao J, Yang Y, et al. Elevated C-reactive protein and monocyte chemoattractant protein-1 in patients with polycystic ovary syndrome. Eur J Obstet Gynecol Reprod Biol. 2011; 157(1): 53-56, doi: 10.1016/j. ejogrb.2011.03.015, indexed in Pubmed: 21530057.

27. Orvieto R, Chen R, Ashkenazi J, et al. C-reactive protein levels in patients undergoing controlled ovarian hyperstimulation for IVF cycle. Hum Reprod. 2004; 19(2): 357-359, doi: 10.1093/humrep/deh089, indexed in Pubmed: 14747180

28. Robinson S, Pemberton P, Laing I, et al. Low grade inflammation, as evidenced by basal high sensitivity CRP, is not correlated to outcome measures in IVF. J Assist Reprod Genet. 2008; 25(8): 383-388, doi: 10.1007/ s10815-008-9253-y, indexed in Pubmed: 18810632.

29. Ganesh Kumar K, Zhang J, Gao Su, et al. Adropin deficiency is associated with increased adiposity and insulin resistance. Obesity (Silver Spring). 2012; 20(7): 1394-1402, doi: 10.1038/oby.2012.31, indexed in Pubmed: 22318315.

30. Akcilar R, Kocak FE, Simsek H, et al. Antidiabetic and hypolipidemic effects of adropinin streoptozotocin-induced type 2 diabetic rats. Bratisl Lek Listy. 2016; 117(2): 100-105, doi: 10.4149/bll_2016_020, indexed in Pubmed: 26830041 